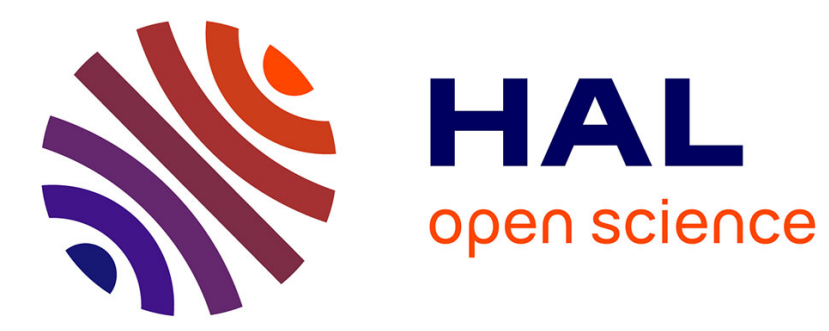

\title{
Novel non-carboxylic acid retinoids: 1,2,4-oxadiazol-5-one derivatives.
}

Julie Charton, Rebecca Deprez-Poulain, Nathalie Hennuyer, Anne Tailleux, Bart Staels, Benoit Déprez

\section{> To cite this version:}

Julie Charton, Rebecca Deprez-Poulain, Nathalie Hennuyer, Anne Tailleux, Bart Staels, et al.. Novel non-carboxylic acid retinoids: 1,2,4-oxadiazol-5-one derivatives.. Bioorganic and Medicinal Chemistry Letters, 2009, 19 (2), pp.489-92. 10.1016/j.bmcl.2008.11.040 . inserm-00360276

\section{HAL Id: inserm-00360276 https://www.hal.inserm.fr/inserm-00360276}

Submitted on 10 Feb 2009

HAL is a multi-disciplinary open access archive for the deposit and dissemination of scientific research documents, whether they are published or not. The documents may come from teaching and research institutions in France or abroad, or from public or private research centers.
L'archive ouverte pluridisciplinaire HAL, est destinée au dépôt et à la diffusion de documents scientifiques de niveau recherche, publiés ou non, émanant des établissements d'enseignement et de recherche français ou étrangers, des laboratoires publics ou privés. 


\title{
Novel non carboxylic acid retinoids: 1,2,4-oxadiazol-5-one derivatives.
}

\author{
Julie Charton ${ }^{\mathrm{a}, \mathrm{c}, \mathrm{d}, \mathrm{e}, *}$, Rebecca Deprez-Poulain ${ }^{\mathrm{a}, \mathrm{c}, \mathrm{d}, \mathrm{e}}$, Nathalie Hennuyer ${ }^{\mathrm{b}, \mathrm{c}, \mathrm{d}}$, Anne \\ Tailleux ${ }^{b, \mathrm{c},}$, Bart Staels ${ }^{\mathrm{b}, \mathrm{c}, \mathrm{d}}$, Benoit Deprez \\ ${ }^{a}$ INSERM U761 Biostructures and Drug Discovery, Lille F-59006, France \\ ${ }^{b}$ INSERM U545, Lille F-59019, France
}

${ }^{c}$ Faculté de Pharmacie, Université Lille 2, Lille F-59006, France

${ }^{d}$ Institut Pasteur de Lille, Lille F-59021, France

${ }^{e}$ PRIM (www.drugdiscovery-lille.org)

This is where the receipt/accepted dates will go; Received Month XX, 2000; Accepted Month XX, 2000 [BMCL RECEIPT]

\begin{abstract}
We have successfully obtained 1,2,4-oxadiazol-5-one bioisoteres of Am580 or Tazarotene-like retinoids. In particular compound 4 displays an $\mathrm{EC}_{50}$ of $26 \mathrm{nM}$ on $\mathrm{RAR}-\beta$.
\end{abstract}

Natural and synthetic retinoids display pleiotropic effects that have led to their development as therapeutic drugs in a number of applications including acne, psoriasis and cancer ${ }^{1}$. Retinoids have a remarkable range of activities. Indeed, they regulate embryonic development, bone formation, cell differentiation and proliferation, glucose and lipid metabolism, carcinogenesis and immune function. ${ }^{2,3,4}$ The biological activities of retinoids are mediated by two types of nuclear receptors, Retinoic Acid Receptors (RARs or NR1B : RAR $\alpha$, RAR $\beta$ and RAR $\gamma$ ), and Retinoid X Receptors (RXRs or NR2B : $\operatorname{RXR} \alpha, \operatorname{RXR} \beta$ and $\operatorname{RXR} \gamma$ ). At the molecular level RARs and RXRs form heterodimers. At the cellular level, these receptors are DNA binding proteins that regulate gene transcription in response to ligand binding. The success of RAR modulation in the treatment of acute promyelocyticleukaemia (APL) ${ }^{5}$ has stimulated considerable interest in the development of RAR and RXR modulators. Most potent retinoids, such as Am580 or Tazarotenic acid have an aromatic carboxylic acid moiety instead of the polyenecarboxylic acid of retinoic acid (ATRA, Figure 1). In this family, the hydrophobic part and the linker (X) can be varied with retention of high activity. Tazarotene, an RAR- $\beta, \gamma$ selective acetylenic retinoid, was chosen for development as a topical agent for psoriasis and acne. Am580 (RAR- $\alpha$ selective) has powerful and selective cyto-differentiating effects on APL. ${ }^{6,7}$

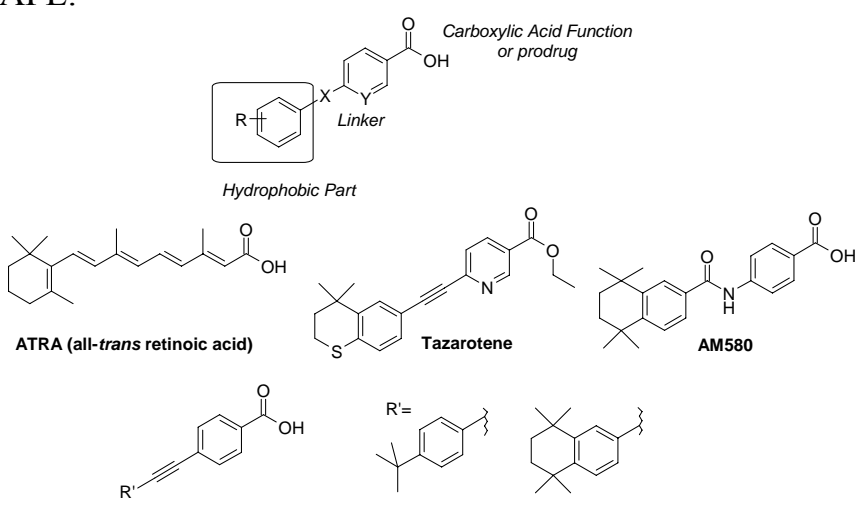

Figure 1: General structure of retinoids and examples. ${ }^{2}$

\footnotetext{
* Corresponding author. Tel.: +33(0)320 964928; fax: +33(0)320964 709, email julie.charton@univ-lille2.fr
} 
Various acidic heterocycles are classically used by medicinal chemists as carboxylic acid bioisosteres. ${ }^{8}$ Tetrazole is a common bioisostere of the carboxylic acid group but in the particular case of retinoids led to loss of activity. ${ }^{9}$ On the contrary, thiazolidinedione moiety has been described by Tashima et al. to be an effective replacement of the carboxylic acid (Figure 2a). ${ }^{10,11}$ More recently, bioisosteric replacement of carboxylic acid with a tropolone ring is reported (Figure 2b). ${ }^{12,13}$
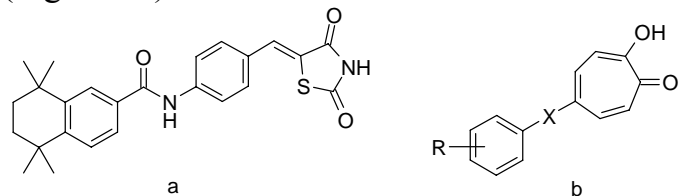

Figure 2 : Non-Benzoic Acid Retinoids.

Another example of acidic heterocycle is the 1,2,4oxadiazol-5-one ring, found in AT1 antagonists ${ }^{14}$, COX inhibitors ${ }^{15}$, PLA2 inhibitors ${ }^{16}$ and modulators of GluR ${ }^{17}$. This heterocycle can replace carboxylic acids but displays geometrically different protomers and slightly different physico-chemical properties. Compounds bearing this heterocycle have different lipophilic properties that may translate into improved bioavailability compared with their carboxylic analogues. Indeed, $\Delta \log \mathrm{D}_{7.4}$ between benzoic acid and 3-phenyl-1,2,4-oxadiazol-5-one $=0.7 \log$ unit, the oxadiazolone being more hydrophobic than its carboxylic counterpart. ${ }^{18}$ In our project aiming at synthesizing various analogues of pharmacologically active carboxylic acids, we explored the replacement of the carboxylic acid function by the 1,2,4-oxadiazol5-one moiety in two series of retinoids: analogues of the tazarotene, a RAR- $\beta, \gamma$ selective acetylenic retinoid, and Am580, an RAR- $\alpha$ selective retinoid (Figure 3).

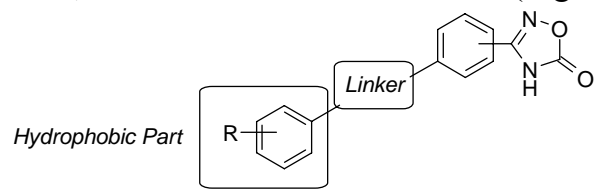

Figure 3: Generic structure of the potential retinoid 1,2,4-oxadiazol-5one derivatives.

First, we investigated the synthesis of tazarotenic acid analogues. ${ }^{19}$ Precursors $\mathbf{1}$ and $\mathbf{2}$ were synthesized as previously described from the corresponding nitrile in two steps (Scheme 1). ${ }^{20}$

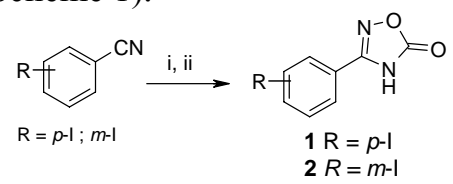

Scheme 1. Reaction conditions: i) $\mathrm{NH}_{2} \mathrm{OH} . \mathrm{HCl}$, DIEA, EtOH, reflux, 8 hrs, (1a: $75 \%$, 2a: $95 \%$ ). ii) CDI, DBU, dioxane, $110^{\circ} \mathrm{C}$, $2 \mathrm{hrs},(1: 80 \%$, 2: $80 \%)$.

We have recently reported a strategy for solid phase synthesis of acetylenic derivatives of 3-aryl-1,2,4oxadiazol-5-one thanks to a Sonogashira reaction.
Compound 1 was thus grafted on resin and then reacted with 6-ethynyl-1,1,4,4-tetramethyl-1,2,3,4tetrahydro-naphthalene $\mathbf{3}$ to yield compounds $\mathbf{4}$ (Scheme 2).

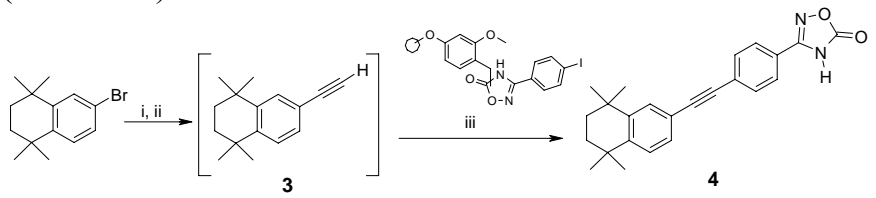

Scheme 2.

Reaction conditions: i) trimethylsilylacetylene (1.3 eq), $\mathrm{PdCl}_{2}\left(\mathrm{PPh}_{3}\right)_{2}$ $(0.05$ eq $), \mathrm{CuI}(0.1 \mathrm{eq}), \mathrm{NEt}_{3}, 70^{\circ} \mathrm{C}, 12 \mathrm{hrs}$. ii) $\mathrm{KOH}(0.1 \mathrm{~N})$, Isopropanol, 12hrs, room temp. iii) alkyne (10 eq), $\mathrm{PdCl}_{2}\left(\mathrm{PPh}_{3}\right)_{2}(1.1$ eq), CuI (2.2eq), DIEA (30 eq), DMF, rt, 3 hrs then $5 \% \mathrm{TFA} / \mathrm{CH}_{2} \mathrm{Cl}_{2}$, rt, 3 hrs

In the search of a more cost-effective synthesis, we also developed the first solution Sonogashira coupling with an unprotected 1,2,4-oxadiazol-5-one ring. Such strategy has been used for Suzuki-Miyaura reactions ${ }^{21}$ and successfully applied for the synthesis of compounds 5-7 (Scheme 3).

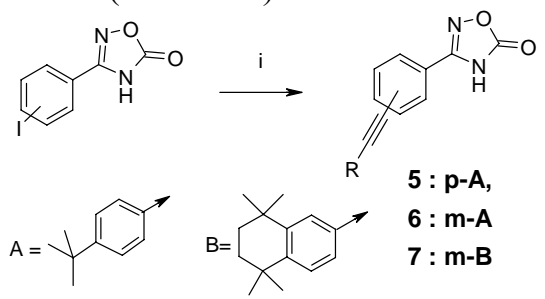

Scheme 3. Reaction conditions: i) 1 or $2, \mathrm{PdCl}_{2}\left(\mathrm{PPh}_{3}\right)_{2}, \mathrm{CuI}, \mathrm{NEt}_{3}$, DMF, $80^{\circ} \mathrm{C}, 7 \mathrm{hrs},(5: 50 \%, 6: 83 \%, 7: 56 \%)$.

Some carboxylic acid analogues described in literature were also synthesized like compounds $\mathbf{8}$ and $\mathbf{9}$ in order to compare retinoidal activity of our oxadiazolone derivatives with known retinoic compounds.

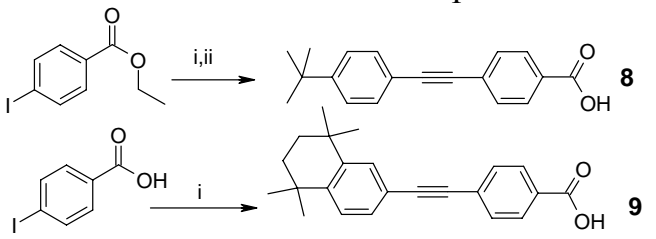

Scheme 4. Reaction conditions: i) Alkyne (1.2 eq), $\mathrm{PdCl}_{2}\left(\mathrm{PPh}_{3}\right)_{2}(0.05$ eq), $\mathrm{CuI}$ (0.1 eq.), $\mathrm{NEt}_{3}, \mathrm{DMF}, 80^{\circ} \mathrm{C}, 5 \mathrm{hrs}, \mathbf{8 a}: 52 \%, 9: 20 \%$, ii) $\mathrm{NaOH}(2 \mathrm{eq}), \mathrm{EtOH}, 8: 100 \%$.

Am580 and its 1,2,4-oxadiazol-5-one analog 10 were synthesized as described in Scheme 5.

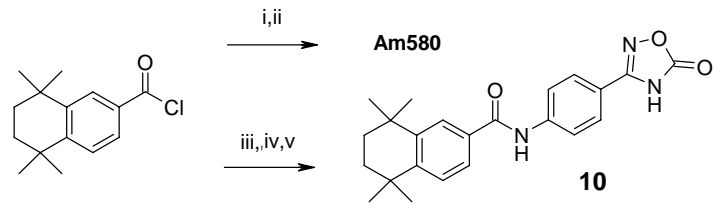

Scheme 5. Reaction conditions: i) $\mathrm{H}_{2} \mathrm{~N}_{-} \mathrm{C}_{6} \mathrm{H}_{4}-\mathrm{CO}_{2} \mathrm{Et}, \mathrm{NEt}_{3}$, THF, rt, 3 hrs, $85 \%$. ii) $\mathrm{NaOH}, \mathrm{EtOH}, \mathrm{H}_{2} \mathrm{O}, 40^{\circ} \mathrm{C}, 12 \mathrm{hrs}, 90 \%$. iii) $\mathrm{H}_{2} \mathrm{~N}_{-} \mathrm{C}_{6} \mathrm{H}_{4}-\mathrm{CN}$, $\mathrm{NEt}_{3}$, THF, rt, 12 hrs, 10a: $98 \%$. iv) $\mathrm{NH}_{2} \mathrm{OH} . \mathrm{HCl}$, DIEA, EtOH, reflux, $6 \mathrm{hrs}$, 10b: $91 \%$. v) CDI, DBU, dioxane, $110^{\circ} \mathrm{C}$, $2 \mathrm{hrs}$, 10: $44 \%$.

The retinoidal activities of the synthesized compounds were examined in terms of potency and efficacy and 
results are presented in Table 1. Chimeric receptors RAR-Gal4 where RAR ligand-binding domain (LBD) fused to the DNA binding domain (DBD) of the yeast transcription factor GAL4 and reporter gene containing a GAL4 response element-driven luciferase activity have been transiently transfected. Mammalian cells did not contain GAL, only the transfected RAR-GAL4 chimeric receptors can activate the reporter gene, eliminating interference from endogenous nuclear receptors. ${ }^{22}$

Table 1: Transcriptional activation assay data. ${ }^{\text {a }}$

\begin{tabular}{|c|c|c|c|c|c|c|}
\hline & RAR- $\alpha$ & & RAR- $\beta$ & & RAR- $\gamma$ & \\
\hline Cpds & $\mathrm{EC}_{50}(\mathrm{nM})$ & $\operatorname{Eff}(\%)$ & $\mathrm{EC}_{50}(\mathrm{nM})$ & Eff(\%) & $\mathrm{EC}_{50}(\mathrm{nM})$ & $\operatorname{Eff}(\%)$ \\
\hline 8 & $>1000$ & $\mathrm{-b}^{\mathrm{b}}$ & 10.0 & $35^{\mathrm{c}}$ & 10.0 & $44^{\circ}$ \\
\hline 5 & $>1000$ & $\mathrm{-b}^{\mathrm{b}}$ & 820.0 & 34 & $>1000$ & $-{ }^{b}$ \\
\hline 6 & $>1000$ & $-\mathrm{b}$ & $>1000$ & $-\mathrm{b}$ & $>1000$ & $-\mathrm{b}$ \\
\hline 9 & 0.6 & 53 & 0.3 & 83 & 0.6 & 125 \\
\hline 4 & $>1000$ & $-^{\mathrm{b}}$ & 26.0 & 50 & 91.0 & 48 \\
\hline 7 & $>1000$ & $-\mathrm{b}$ & $>1000$ & $-{ }^{b}$ & $>1000$ & $-{ }^{b}$ \\
\hline Am580 & 0.3 & 43 & 8.6 & 46 & 13.0 & 43 \\
\hline 10 & 520.0 & 40 & $>1000$ & $-\mathrm{b}$ & $>1000$ & $-\mathrm{b}$ \\
\hline Tazarotene & 63.0 & 54 & 0.8 & 57 & 40.0 & 72 \\
\hline ATRA & 17.0 & 100 & 12.0 & 100 & 0.2 & 100 \\
\hline
\end{tabular}

${ }^{a}$ The data are expressed as averages of $\%$ efficacy and $\mathrm{EC}_{50}$. Eff. : efficacy is relative to ATRA defined as $100 \%$.

${ }^{\mathrm{b}}<10 \%$ at $10 \mu \mathrm{M}$.

${ }^{\mathrm{c}}$ Efficacy is relative to Tazarotene defined as $100 \%$.

Tazarotene and its analogue $\mathbf{8}$ are RAR- $\beta, \gamma$ selective acetylenic retinoids, whereas analogue $\mathbf{9}$ is very active on the three subtypes. Interestingly, 1,2,4-oxadiazol-5one $\mathbf{4}$ and 5 activities differ from their carboxylic acids analogues. Indeed, compound $\mathbf{5}$ is slightly active on RAR- $\beta$. Compound 4, though nanomolar on RAR- $\beta$ $\left(\mathrm{EC}_{50}=26 \mathrm{nM}\right)$, is less active than 9 but displays a better selectivity on RAR- $\beta, \gamma$ subtypes and an efficacy comparable with tazarotene. As expected, bended analogue 7 is not active since it is not linear enough to fit the RAR pharmacophore. In the second series, compound $\mathbf{1 0}$ is active on RAR- $\alpha$ with a similar efficacy to that of Am580 (40 versus $43 \%$ ). In the light of these results, both compounds $\mathbf{4}$ and $\mathbf{1 0}$ could be good starting points for further optimization.

All these compounds were checked for cross-reactivity with the retinoid $\mathrm{X}$ receptor $(\operatorname{RXR} \alpha, \beta, \gamma)$ and found to be inactive.

In conclusion, we have described the solid-phase or solution-phase syntheses of a new series of non carboxylic acid RAR ligands. We have shown that the 1,2,4-oxadiazol-5-one moiety can act as a bioisostere of the carboxylic acid function in retinoid structures. In particular the retinoidal activity of compound 4 (RAR- 
$\beta, \gamma$ selective) is significant, considering that replacement of the carboxylic acid in retinoid structures with bioisosteric functional groups is generally ineffective. These non carboxylic acid type RAR ligands may exhibit different pharmacological behaviors from classical carboxylic acid compounds, as well as unique biological activity, and they may provide further scope for clinical applications.

\section{Acknowledgements}

We are grateful to the Institutions that support our laboratory (Inserm, Université de Lille2 and Institut Pasteur de Lille). Data management was performed using Pipeline Pilot ${ }^{\mathrm{TM}}$ from Scitegic. We thank also the following Institutions or companies: CAMPLP and VARIAN.inc. This project was supported by the Fondation pour la Recherche Medicale (FRM) - NordPas-de-Calais.

\section{Supplementary data}

Supplementary data associated with this article can be found for the online version.

${ }^{1}$ Altucci, L.; Leibowitz, M. D.; Ogilvie, K. M.; de Lera, A. R.; Gronemeyer, H. Nat Rev Drug Discov 2007, 6, 793.

${ }^{2}$ Thacher, S. M.; Vasudevan, J.; Chandraratna, R. A. Curr Pharm Des 2000, 6, 25.

3 Altucci, L.; Gronemeyer, H. Nat Rev Cancer 2001, 1, 181.

${ }^{4}$ de Lera, A. R.; Bourguet, W.; Altucci, L.; Gronemeyer, H. Nat Rev Drug Discov 2007, 6, 811.

${ }^{5}$ Lengfelder, E.; Saussele, S.; Weisser, A.; Büchner, T.; Hehlmann, R. Critical Reviews in Oncology/Hematology 2005, 56, 261.

${ }^{6}$ Kagechika, H.; Kawachi, E.; Hashimoto, Y.; Shudo, K.; Himi, T. J. Med. Chem. 1988, 31, 2182.

${ }^{7}$ Gianni, M.; Li Calzi, M.; Terao, M.; Guiso, G.; Caccia, S.; Barbui, T.; Rambaldi, A.; Garattini, E. Blood 1996, 87, 1520.

${ }^{8}$ Wermuth, C.G. in The Practice of Medicinal Chemistry, edited by Wermuth, C.G. 2nd Edition, 2003, Academic Press, London, pp 189-214.

${ }^{9}$ Dawson, M. I.; Hobbs, P. D.; Kuhlmann, K.; Fung, V. A.; Helmes, C. T.; Chao, W.-R. J. Med. Chem. 1980, 23, 1013.

${ }^{10}$ Tashima, T.; Kagechika, H.; Tsuji, M.; Fukasawa, H.; Kawachi, E.; Hashimoto, Y.; Shudo, K. Chem Pharm Bull (Tokyo) 1997, 45, 1805.

${ }^{11}$ Ebisawa, M.; Kawachi, E.; Fukasawa, H.; Hashimoto, Y.; Itai, A.; Shudo, K.; Kagechika, H. Biol Pharm Bull 1998, 21, 547.

${ }^{12}$ Ebisawa, M.; Ohta, K.; Kawachi, E.; Fukasawa, H.; Hashimoto, Y.; Kagechika, H. Chem Pharm Bull (Tokyo) 2001, 49, 501.

${ }^{13}$ Kagechika Hiroyuki Nerima-Ku, EP 1357104 A1

${ }^{14}$ Kohara, Y.; Kubo, K.; Imamiya, E.; Wada, T.; Inada, Y.; Naka, T. J Med Chem 1996, 39, 5228.

${ }^{15}$ Boschelli, D. H.; Connor, D. T. May 19, 1992; Patent
US 5,114,958.

${ }^{16}$ Dong, C.-Z.; Ahamada-Himidi, A.; Plocki, S.; Aoun, D.; Touaibia, M.; Meddad-Bel Habich, N.; Huet, J.; Redeuilh, C.; Ombetta, J.-E.; Godfroid, J.-J. Bioorg. Med. Chem. 2005, 13, 1989.

${ }^{17}$ Valgeirsson, J.; Nielsen, E. O.; Peters, D.; Mathiesen, C.; Kristensen, A. S.; Madsen, U. J Med Chem 2004, 47, 6948.

${ }^{18}$ Measured with shake-flash method, UV detection.

19 Patent US5,349,105, Allergan, issued $20^{\text {th }}$ September 1994.

${ }^{20}$ Charton, J.; Cousaert, N.; Bochu, C.; Willand, N.; Deprez, B. and Deprez-Poulain, R. Tetrahedron Lett. 2007, 48,1479 .

${ }^{21}$ Stansfield, I.; Pompei, M.; Conte, I.; Ercolani, C.; Migliaccio, G.; Jairaj, M.; Giuliano, C.; Rowley, M. and Narjes, F. Bioorg. Med. Chem. Lett. 2007, 17, 5143.

${ }^{22}$ Cell culture. Cos-7 cells were obtained from ATCC (CRL-1651). Cells were maintained in standard culture conditions (Dulbecco's modified Eagle's minimal essential medium supplemented with $10 \%$ fetal calf serum at $37^{\circ} \mathrm{C}$ in a humidified atmosphere of $5 \% \mathrm{CO}_{2} / 95 \%$ air). Medium was changed every 2 days.

Effect of compounds on RARs transcriptional activity using chimaeric protein constructs.Cos-7 cells were seeded in $60 \mathrm{~mm}$ dishes in DMEM supplemented with $10 \%$ FCS and incubated at $37^{\circ} \mathrm{C}$ for $16 \mathrm{~h}$ prior transfection. Cells were transfected in DMEM $10 \%$ FCS, using jetPEI ${ }^{\mathrm{TM}}$ transfection reagent, with reporter (pGal5-TK-pGl3) and expression plasmids ( $\mathrm{pGa} 4 \mathrm{4}-\mathrm{hRAR} \alpha, \gamma$, or $\beta$ ). Cells were incubated at $37^{\circ} \mathrm{C}$. After $24 \mathrm{~h}$, cells were trypsinised and seeded in 96-well plates and incubated for 6h in DMEM containing $0.2 \%$ FCS. Cells were then incubated $16 \mathrm{~h}$ in DMEM $0.2 \%$ FCS and increasing concentrations of the compounds tested or vehicle (DMSO). At the end of the experiments, cells were washed once with PBS and the luciferase and the $\beta$-galactosidase assays were performed. 